\title{
A first glance into the black box of life satisfaction surrounding childbearing
}

\author{
Arnstein Aassve ${ }^{1} \cdot$ Francesca Luppi $^{2} \cdot$ Letizia Mencarini ${ }^{3}$
}

Accepted: 1 June 2021 / Published online: 13 June 2021

(c) The Author(s) 2021

\begin{abstract}
The vast majority of studies looking into the relationship between childbearing and subjective well-being use overall measures where respondents either report their general level of happiness or their life satisfaction, leaving substantial doubt about the underlying mechanisms. However, life satisfaction and happiness are intuitively multidimensional concepts, simply because there cannot be only one aspect that affects individuals' well-being. In this study, by considering seventeen specific life satisfaction domains, these features come out very clearly. Whereas all the domains considered matter for the overall life satisfaction, only three of them, namely satisfaction with leisure, health and satisfaction with the partnership, change dramatically surrounding childbearing events. Even though we cannot generalise (since these results stem from one particular panel survey, i.e., Household Income and Labour Dynamics in Australia data), it appears that the typical anticipation and post-child decrease of life satisfaction, so often found in existing studies, stems from changes in these three domains.
\end{abstract}

Keywords Life satisfaction · Domains of satisfaction · Childbearing · Longitudinal analysis

Letizia Mencarini

letizia.mencarini@unibocconi.it

1 DONDENA Centre for Research on Social Dynamics and Department of Social and Political Science, Bocconi University, Via Sarfatti 25, 20136 Milan, Italy

2 Department of Statistics, Università Cattolica del Sacro Cuore, Largo Gemelli 1, 20123 Milan, Italy

3 DONDENA Centre for Research on Social Dynamics and Department of Management, Bocconi University, Via Sarfatti 25, 20136 Milan, Italy 


\section{Introduction}

With value change and modernisation (Inglehart, 1977, 1989), all Western countries experienced a sustained fertility decline (Billari \& Kohler, 2004; Morgan, 2003). With this new fertility regime, proponents of the Second Demographic Transition (Lesthaeghe \& van de Kaa, 1986) argue that self-realisation has taken priority over family life and children. Studies have consequently focussed on establishing the relationship between childbearing events and self-reported well-being, with the idea that satisfaction may decline with the onset of children (Aassve et al., 2012, 2015; Clark et al., 2008; Frijters et al., 2011; Le Moglie et al., 2015; Margolis \& Myrskylä, 2011; Matysiak et al., 2016; Myrskylä \& Margolis, 2014; Pollmann-Schult, 2014). The majority of these studies use a general measure of individuals' reported happiness or overall life satisfaction. Intuitively one would expect one's overall life satisfaction to be derived from a range of sources. Satisfaction with leisure time, with the financial situation, or with work-life balance-just to mention a few-all add up to the broader and more general life satisfaction measure. With an aim of understanding patterns of well-being across time and societies, such an overall measure may suit the purpose well. However, in a life course perspective, individuals' priorities and preferences change according to the life stage in which they find themselves. As for childbearing, which is such a pervasive event in couples' lives, where one is forced to shift efforts and attention towards the new-born child, the satisfaction domains may also shift in significant ways. As policy makers are concerned about declining fertility levels, it is a pertinent need to understand which domains matter more for the satisfaction surrounding childbearing events.

The main contribution of this study is to consider a range of domains of satisfaction, all of which are being held up against childbearing events. Existing studies, based on overall measures of individuals' reported life satisfaction, show an upward trend prior to the actual childbearing event (and often this takes place prior to the date of conception), and then, to taper off after some years. These effects, respectively, are typically interpreted as processes of anticipation and adaptation. We use the Household Income and Labour Dynamics in Australia (HILDA), where one unique feature is that it has repeated recordings over time of satisfaction across several satisfaction domains. In line with previous studies (Clark et al., 2008; Le Moglie et al., 2018; Margolis \& Myrskylä, 2011; Myrskylä \& Margolis, 2014; Pollmann-Schult, 2014), we estimate a series of fixed effect models, where reported satisfaction in these domains are used as dependent variables, while childbearing events are incorporated as explanatory variables - together with a set of control variables. We complement the standard fixed effect regression with a Blinder-Oaxaca (1973) decomposition exercise. This approach provides statistical evidence as to which domains matter more in driving the overall life satisfaction surrounding the childbearing event. When comparing overall satisfaction with those of the domains, we find that only a limited number of them react to the childbearing event. For the majority of the domains, childbearing has little or no impact on the reported satisfaction. The study consequently brings insights into why life-satisfaction changes surrounding childbearing. 


\section{Background}

\section{Subjective well-being and childbearing}

There is now a number of longitudinal studies focusing on the dynamics of Subjective Well-being (henceforth, SWB) surrounding childbearing events. In the majority of cases, SWB is measured through reported happiness, or overall life satisfaction. In general, independent of the measure used, it tends to increase prior to the actual childbearing event itself, a feature typically referred to as an anticipation effect. It is then followed by a significant decline, especially during the first year of life of the child - a pattern that is again rather robust across Western countries where panel surveys are available. Clark et al. (2008) and Le Moglie et al. (2018), using the German socio-economic panel (SOEP), Myrskyla and Margolis (2014) using both the SOEP and the British Household Panel Survey (BHPS), Frijters et al. (2011) and Matysiak et al. (2016), using the Australian household panel (HILDA), all show clear positive anticipation with respect to the childbearing event, followed by a decrease of SWB in the period after the event took place.

The relationship between childbearing and SWB depends on several preconditions and mediating factors (Kohler \& Mencarini, 2016). For instance, SWB trajectories vary by the parents' age, gender, and socio-economic status (Le Moglie et al., 2018; Margolis \& Myrskylä, 2011; Myrskylä \& Margolis, 2014), and, to some extent, the country where the parents live (Aassve et al., 2012, 2015). Studies also show that the SWB trajectory associated with the second child is different from the first (Le Moglie et al., 2015; Myrskyla \& Margolis, 2014). As prospective parents would have no experience about the impact of childbearing the first time around, they may exaggerate the potential positive feelings about parenthood, and possibly underestimate the upheavals the addition of a new young family member entails. As Myrskyla and Margolis (2014) point out, positive expectations before the onset of parenthood are frequently overoptimistic. The SWB trajectory surrounding the second child is less pronounced but also more heterogeneous across samples.

Making expectations about one's future with a child is clearly part of the planning process that individuals make. Future parents aim to predict consequences of parenthood along several life spheres (work, couple relationship, leisure time, health, etc.). This means that the way individuals emotionally react to childbearing depends on the match (or perhaps mismatch) between expectations and the eventual reality when childbearing takes place. The anticipation of the potential consequences in terms of labour market involvement, often begins early, especially for women (Bass, 2014). As several studies have shown, the transition to parenthood leads to divergent gender paths both in terms of the pay-gap and career opportunities (Grunow et al., 2012; McDonald, 2000). Moreover, women, more than men, consider their fertility intentions when making career choices, and this is especially so among those from a higher socio-economic background. Where higher education delays childbearing, it also brings about better security 
in terms of career prospects and higher economic resources. Women's concern about work-family balance is justified by the fact that they usually become the primary caregiver of their children (Baxter et al., 2015; Cowan \& Cowan, 1992; Craig et al., 2010; Goldberg \& Perry-Jenkins, 2004). Not surprisingly, difficulties in reconciling work and family after the first childbirth are one of the main causes of the decline of mothers' SWB, at least in the short run (Matysiak et al., 2016). In addition to these factors, the personality of the child itself plays a role. For instance, a child's sleep patterns will necessarily affect the well-being of the parents. Likewise, health problems will potentially affect parental well-being (Brehaut et al., 2011; Davis et al., 2009).

\section{Overall life satisfaction and its domains}

Research in psychology suggests that SWB encompasses both an emotional dimension-i.e., positive and negative affects—and a cognitive dimension-i.e., life satisfaction (Andrews \& Withey, 1974). Life satisfaction is an evaluative judgment on one's life, related to the immediate or very recent context (Schwarz \& Strack, 1991). There is an extensive literature concerning the association between life satisfaction and its domains (for a review see Lance et al., 1989). It derives from the simple fact that life satisfaction is necessarily multidimensional. The intuition is simple. Individuals have various needs, and their overall satisfaction depends on the extent to which those needs are satisfied. In social psychology there is consequently an approach known as the "domains of life" (Cummins, 1996; Saris \& Ferligoj, 1995; Veenhoven, 1996). It posits that overall well-being depends on satisfaction with each of several life spheres (Campbell et al., 1976).

The domain specific approach prompts individuals' memories about that particular domain, which they often find easier than expressing a precise value of overall satisfaction (Pavot \& Diener, 2008; Bargh, 1989; Schwarz et al. 1987). Whereas individuals derive satisfaction from various sources, it is not obvious which domains weigh more (or less) towards overall SWB. The relative importance depends on life events, values, pursued goals (Kasser \& Ryan, 1996; Oishi et al., 1999), expectations (Veenhoven, 1996) and life stages (Cantor \& Blanton, 1996). Obviously, there is heterogeneity in how those elements matter for individuals (Oishi et al., 1999; Trauer \& Mackinnon, 2001; Wu, 2009).

Certain domains have been found particularly relevant for describing the overall SWB (Cummins, 1996). These are satisfaction with health, family, social relationships, leisure-time, work, sex, income, housing, safety, self-worth, and education (Argyle, 2001; Costa, 2008; Greenley et al., 1997; Headey \& Wearing, 1992; Praag et al., 2003). Over the life course, individuals change their perception about which life domains are more important for their overall wellbeing (Cantor \& Sanderson, 1999; Diener et al., 1999). For example, satisfaction with the couple relationship weighs more strongly during the early stages of the family formation process (Oishi et al., 1999), while health becomes a more important domain in old age (Steptoe et al., 2015). However, independently from the stage of life the individual is experiencing, two domains relate more strongly with overall measures of SWB: social 
relationships and work (Argyle \& Martin, 1991). Social relationships are themselves sources of material help and social support, and they help prevent individuals from experiencing illness and mental distress. However, social relationships can be also sources of dissatisfaction. For example, the partners' relationship can be one of the strongest sources of conflict and therefore yield low SWB (Argyle \& Furnham, 1983). The work domain is relevant simply because it is such a dominant component of an individual's identity (Furnham, 1991). Likewise, leisure is a source of intrinsic satisfaction (Veroff et al., 1981), because leisure activities tends to positively affect one's self esteem (Kabanoff, 1982). Moreover, both work and leisure are important sources of social relationships, thereby enhancing social satisfaction.

The question of how satisfaction with specific life domains may change with the arrival of a child has been partially addressed in some studies. None of them, however, aim to assess the relative importance of each domain in describing the trend of parents' overall life satisfaction across the transition to parenthood. Krämer and Rodgers (2019) explore German SOEP (Socio Economic Panel study) data, and in particular how satisfaction with the overall life and some life domains (life, family life, health, sleep, job, housework, household income, personal income, leisure and dwelling) change and adapt to the arrival of the first child. They found that satisfaction with personal income significantly declines for mothers after the birth of the child, but not for fathers; satisfaction with sleep also declines for both parents. Bernardi and colleagues (2017) find that in Germany (using SOEP data) mothers more than fathers decrease their satisfaction with job and leisure time after the transition to parenthood. Accordingly, a UK study (Georgellis et al., 2012) finds that the birth of the first child has a long-lasting negative effect on job satisfaction for both mothers and fathers. These results might be explained by the following mechanisms. For women, childbearing brings about an interruption to their work career, and as such, childbearing may affect mothers' career prospects, while the "second-shift" may increase work-family conflict (Matysiak et al., 2016). Moreover, time for leisure also becomes reduced, as mothers have to adjust to the child's needs, especially during the period when the child is very young. Fathers on the other hand, continue to work in most cases, but they may become more sensitive to the financial domain, as they are concerned with guaranteeing an adequate standard of life to their enlarged family. However, compared to mothers, they seem to be favoured in terms of domestic responsibilities and leisure (e.g., Yavorsky et al., 2015).

Additionally, it has been shown that receiving support from relatives, and especially from the new grandparents, is important during the period surrounding childbirth and the time immediately afterwards. Having children and not having informal help from grandparents, for example, may even worsen mothers' satisfaction with their work-family balance (Arpino \& Luppi, 2020). Thus, satisfaction with family relationships is important, and can potentially change during the period before and after childbirth (Liefbroer, 2005; Melender \& Lauri, 2002).

Among family relationships, the couple relationship is certainly the one more affected by the arrival of a child. Building and maintaining a strong couple intimate relationship is an important element in early adult life, but it becomes even more crucial when planning to have a child. Its relevance continues once the child is born as parents have to adjust their commitments to work and family tasks, which may 
bring about conflict and reduce marital satisfaction (Doss et al., 2009; Keizer, 2013; Twenge et al., 2003). However, the housework domain might matter more for mother's SWB than for fathers', because she usually takes most of the domestic responsibility after the childbirth. In fact, evidence in the literature shows that womenbut not men-who perceive not having an equal share of domestic workload with the partner, show a lower relationship satisfaction if compared to those reporting an equal share (Mikula et al., 2012, Ruppanner et al., 2017). In general, the couple's overall lifestyle changes after the arrival of the newborn, and this may trigger stress for both parents (Condon et al., 2004). Finally, childbearing can also imply significant changes to the mother's physical health (Kline et al., 1998), declining their perceived health status, which in turn may negatively affect women's psychological well-being (Webb et al., 2008).

\section{Data, sample and variables}

We use thirteen waves of data from 2001 to 2013 of the Household Income and Labour Dynamics in Australia survey (HILDA). It is a representative sample of Australian households collecting information about family and labour dynamics, economic and subjective well-being on all the adult members of the households. The original sample at the first wave (2001) was made of 7682 households (around 20,000 individuals) and topped up in 2011. A unique part of the HILDA is that it includes repeated measures of overall life satisfaction and satisfaction with seventeen specific domains. These are (1) satisfaction with the relationship with the partner, (2) Leisure time, (3) Work-Family balance, (4) Employment prospects, (5) Financial situation, (6) Health, (7) Work, (8) Pay, (9) Job Security, (10) Working hours, (11) The job in general, (12) The home, (13) Safety, (14) Community, (15) Neighbourhood, (16) Relationship with parents, and (17) Relationship with the child. Satisfaction with the domains is asked yearly, through the question "How satisfied are you with [the domain]?" on an 11-point scale ranging from zero (completely unsatisfied) to 10 (completely satisfied).

We consider men and women who experienced the first birth and potentially the second child. The final sample is made up of 1061 women (aged 18-50) and 946 men (aged 18-60) at the year of the birth of their first child, and 904 women (aged 18-50) and 750 men (aged 18-60) at the year of the birth of their second child. Individuals are followed over a period of 9 years, from 4 years before the year of birth of the child to 4 years after. The year prior to the childbirth is taken as the pregnancy year. Among those experiencing the first birth during the survey, about $60 \%$ also experience the second birth in the subsequent 4 years. The sample is unbalanced due to attrition resulting from missing values on either the satisfaction variables or key explanatory variables.

We include similar control variables as used in previous studies. Other control variables traditionally included in the literature on fertility are also available. Age is measured by five age classes (less or equal than $25 ; 26-30 ; 31-35 ; 36-40$; more than 40), while education is divided in three classes: (1) primary (those who does not reach the end of the secondary school), (2) secondary and advanced diploma, 
tertiary and (3) postgraduate education. Income refers to equivalent disposable household income (net of taxation and divided by the number of household members). Health status is measured on a five-point scale and refers to objective limitations in daily life activities because of health problems. Work status is derived from working hours per week and we distinguish those working part-time, full-time, and more than $40 \mathrm{~h}$ per week, and those not working at all. The percentage of unemployed women or men is small (around 4-5\%). Consequently, inactive and unemployed respondents are lumped together. While there is not much variability within the distribution of working hours over time in the sample of men, the birth of the first child strongly increases the percentage of inactive women (from 12\% 2 years before the birth to $41 \%$ the year after the birth) or women working less than fulltime hours (from 17 to $45 \%$ in the same period).

Finally, we control for whether other life events happen during the period of study. In particular, we include a control for the occurrence of another pregnancy and another birth (first, second or third order), for the presence of another (first, second or third) child aged 1 year or more, and for the respondent getting married.

\section{Methods}

We undertake fixed effects regressions-separate for women and men for each of the domains of satisfaction. We include time dummies for the 4 years before and the 4 years after the birth of the child, using a, reference category 4 years before the event. The model for the individual's satisfaction over time $\left(\mathrm{S}_{\mathrm{it}}\right)$ is defined as:

$$
\mathrm{S}_{i t}=\mathrm{a}_{i}+\mathrm{bX}_{i t}+\mathrm{T}_{t}+\varepsilon_{i t}
$$

where $\mathrm{T}_{t}$ refers to the time dummies, $\mathrm{X}_{i t}$ is the vector of the time-dependent covariates, $\mathrm{a}_{i}$ captures individual level unobserved heterogeneity and $\varepsilon_{i t}$ is the vector of the residuals. From its estimation, we show the time paths of the satisfaction variables to see to what extent the domains are similar (or differ) to the overall life satisfaction path. They consequently provide an indication of the domains' sensitivity with respect to the childbearing events. The models are estimated, and the trajectories plotted, by gender and birth order.

In Sect. 5 we present the results from a Blinder and Oaxaca (1973) decomposition exercise. In particular, the dependent variable is overall life satisfaction, whereas groups are defined over two time points. In the first set of analyses, we compare the year of the pregnancy and 1 year after. In the follow up, we also compare the year of childbirth, and subsequent periods. The explanatory variables of interest are the full set of domain specific satisfaction. We are consequently able to establish the extent to which the gap is explained by the differences in the mean values of the satisfaction domains. 
Women - Overall life satisfaction

8.5

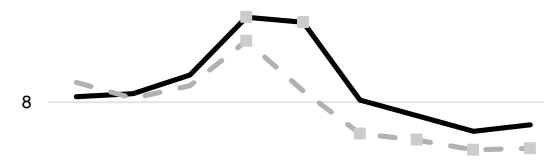

7.5

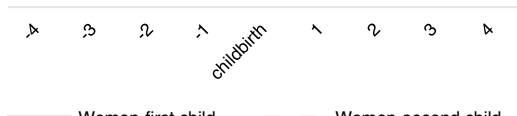

Men - Overall life satisfaction

8.5

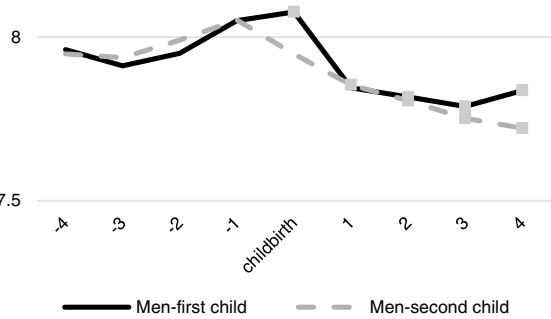

Fig. 1 Trajectories over time of overall life satisfaction, for women and men, across the transition to the first and the second child (predicted values from multivariate regression with fixed effects. Reference categories: 4 years before childbirth; 31-35 years old; primary education; working full-time). Note 1: control variables are age classes, working conditions-i.e., inactive/unemployed; part-time less than $36 \mathrm{~h} /$ week; full-time 36-40 h/week; full-time more than $40 \mathrm{~h} /$ week, equivalent household income, health conditions, experience of separation/divorce, experience of death of partner/close relative or friend, pregnancy of another child, birth of another child, age classes, level of education. Note 2: dots indicate the coefficient is significant at least at $p=0.05$

\section{Results from fixed effect regression}

From the fixed effect estimation, ${ }^{1}$ we start by plotting the estimated overall life satisfaction trends for women and men around the birth of the first and second child (Figs. 1 and 2). The dots indicate statistical significance at the 5\% level, at least. The overall satisfaction shape is consistent with the main results in the literature. For the transition to first child, both women and men show an anticipation effect that is manifested by an increase in estimated life satisfaction. After the birth of the child, satisfaction decreases, with a slight tendency of recovery at the fourth year. Anticipation is more evident for women than for men. For mothers, the increase in life satisfaction is significant for the year before the birth of the child. The year of the first childbirth is associated with a higher level of life satisfaction for both the parents, while it is not the case for the second birth. After the first birth, life satisfaction declines for both genders, but the decrease is significant only for men. After the second birth, the decrease is strong and significant for both women and men.

In order to compare the trend of overall satisfaction with trends in the life domains, we plot the coefficients of the fixed effects models for each of these (see Figs. 1 and 2; Figs. 3 and 4 in Appendix). The first aspect to notice is that the domain specific satisfaction patterns are in many cases at a quite different level compared to overall satisfaction. For the transition to first child, most of the domains do not show significant variations surrounding the childbearing event. Eight of them do not react explicitly to the childbirth event. Some of these domains remain stable across the

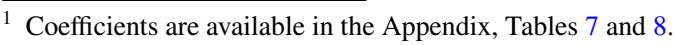


entire time span (such as the domains of job security and housing), whereas others show a monotonic increase or decrease if compared to 4 years before the birth of the child - thus they cannot easily be associated with the childbirth itself. These latter domains include satisfaction with job, pay, work, working hours, feeling of belonging to the community and neighbourhood. The other eight domains show significant changes in the level that can be associated with the parenting experience. Among them, we find three domains that stand out because they show the typical path of anticipation and decline surrounding the childbearing event. These are satisfaction with the partner relationship; leisure time and health (see Figs. 1 and 2). ${ }^{2}$ Satisfaction with the partner increases more for men before the birth of the first child, whereas the decline afterwards is less pronounced compared to women. As for satisfaction with leisure time, we see a rather dramatic decline for women. The decline for men is also noticeable but compared with women, it is less pronounced. A similar trajectory can be seen for the satisfaction with health, where a slight increase at the pregnancy year-for women, but not for men-is followed by a continuous decline after the birth, for both parents. Importantly, for neither of these domains, do we see any indication that women's satisfaction returns to the original level observed prior to the childbearing event.

When considering the second child, the patterns are less pronounced, though for women, the decline in satisfaction with leisure still stand out. For this domain we see a very sharp decline during the year of pregnancy. From the time of the birth of the second child, we also see an important trend of recovery in this domain, but it never reaches the original level. The other domains show less dramatic trends, though for women, we do see a steady decline in the satisfaction with the partner and health. There is no peak surrounding the childbearing event however, though the decline appears to become sharper one year before the birth event. The systematic loss of satisfaction after the second birth is especially evident for mothers, who do not show adaptation in partners' relationship, leisure time nor health domains. In this sense, the second child appears as a rather "detrimental event" in terms of mothers' well-being — and for some domains, the decline appears long lasting.

The implication of these estimates is that when considering the shape of overall life satisfaction surrounding first childbirth for women-typically manifested by a positive anticipation effect, then followed by a decline and a return to the original baseline level - the main drivers come from the satisfaction with leisure time, health and the partner relationship. This is not to say that none of the other domains matter, however. Whereas the satisfaction with the work-family balance, the employment prospects, the financial situation, the relationship with the parents and the feeling of safety do not peak surrounding the childbirth, they do change over the observed time period. For instance, the trend of satisfaction with the work-family balance declines strongly for women from 2 years after the birth of the second child, which is when many mothers go back to work. The positive effect for men after the first birth and the evident negative trend for women after the second birth might be due to the fact

\footnotetext{
2 The same graph has been plotted for the sub-sample of cases which do not show missing values in any of the domains of life satisfaction (see Appendix, Fig. 4).
} 
Fig. 2 Trajectories over time of three domains of satisfaction (partner relationship, health and leisure time) and of the overall life satisfaction, for women and men, across the transition to the first and second child (fixed effects, controlling for socio-demographic characteristics and other life events. Reference categories: 4 years before childbirth; 31-35 years old; primary education; working full-time). Note 1: control variables are age classes, working conditions-i.e., inactive/unemployed; part-time less than $36 \mathrm{~h} /$ week; full-time 36-40 h/week; full-time more than $40 \mathrm{~h} /$ week, equivalent household income, health conditions, experience of separation/divorce, experience of death of partner/close relative or friend, pregnancy of another child, birth of another child, age classes, level of education. Note 2: dots indicate the coefficient is significant at least at $p=0.05$

that, in Australia, women take care of most of the responsibilities for the household tasks - and especially childcare (Baxter et al., 2015; Craig et al., 2010). The norm in Australia, is that in couples with young children, the male partner is regularly the main income provider, and the woman does not work or works part-time (OECD family database, 2012). As a consequence, women's career prospects are not necessarily greatly affected by the arrival of the first child - because they may in any case expect a lower involvement in the labour market—while the second child, instead, increases the double burden of working mothers, leading to an unforeseen reduction of career dedication or employment opportunities. On the contrary, the negative trend of the satisfaction for men's employment prospects might be due to increasing family needs and priorities, which take time away time from work. This potentially relates to men's loss of satisfaction with the financial situation at the year after the birth of the first child. Grandparents seem to provide important support to first time mothers' well-being, especially during the pregnancy and the first year of life of the child. In fact, the satisfaction with the parents' relationship increases for women during this time. However, after the birth of the child, the satisfaction with the parents' relationship declines, especially for men. At the same time, consistent with previous literature, social support received by relatives and friends during the pregnancy and the early years of the first child appears to be responsible for the increase in the feeling of safety for both mothers and fathers (Liefbroer, 2005; Melender \& Lauri, 2002).

\section{Decomposition analysis}

Following up on the analysis in Sect. 4, we implement here a decomposition analysis for the sample of those becoming parents for the first time. This approach provides statistical evidence as to which satisfaction domain matters for overall life satisfaction. We use the well-known Blinder-Oaxaca decomposition approach (Blinder, 1973; Oaxaca, 1973), where the idea is to establish the relative importance of a set of factors with respect to any outcome variable (Jann, 2008). The approach is widely used in labour economics, where, for instance, one is interested in drivers behind the pay gap between men and women. As always, the method distinguishes the importance of explanatory variables into the explained part (i.e., by group differences on certain explanatory factors), and, in an unexplained part (residuals). In our case, the two groups are represented by individuals at the pregnancy year and one year after the first childbirth, where the dependent variable is overall life satisfaction and the 

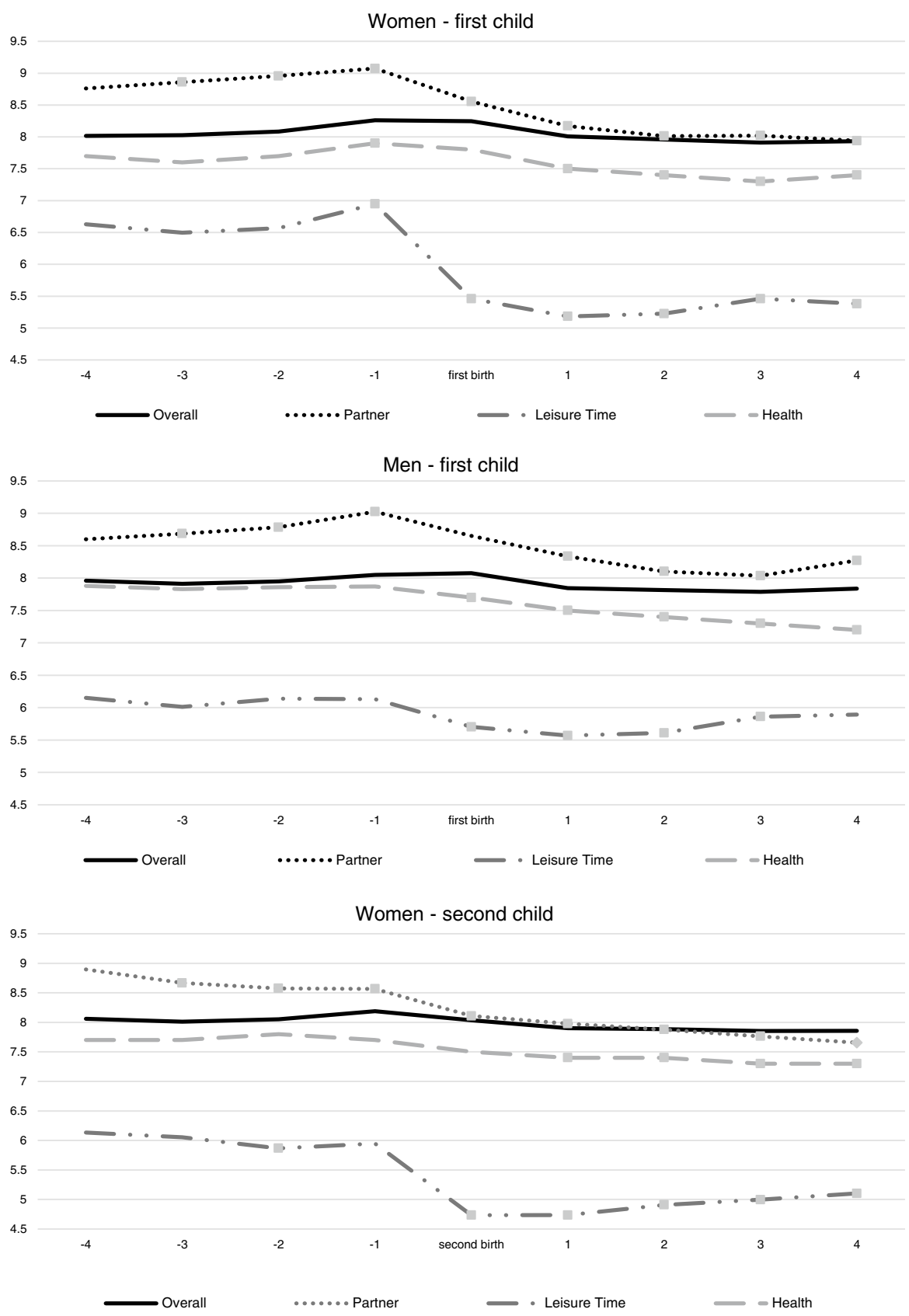

explanatory factors are the domains of life satisfaction. The analysis is undertaken separately for men and women.

Table 1 shows the "Overall" result of the decomposition analysis and the explained part (Endowments), which is the one assessing the relative importance of each domain 


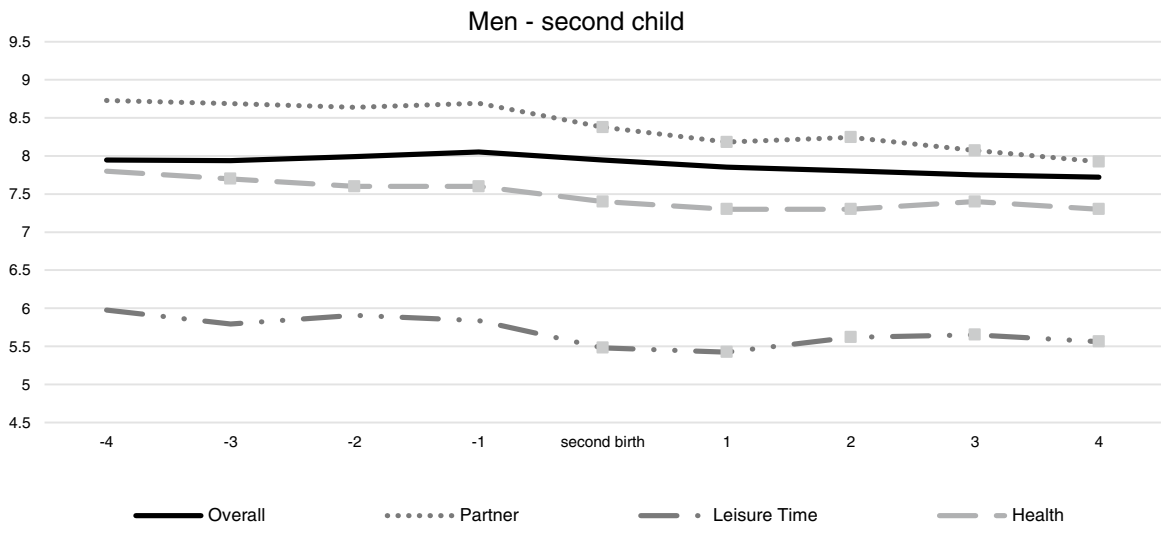

Fig. 2 (continued)

Table 1 Decomposition analysis of the differential in life satisfaction before and after the arrival of the first child explained by differences in satisfaction with life domains (separated models for women and men)

\begin{tabular}{|c|c|c|}
\hline Overall & Men & Women \\
\hline \multicolumn{3}{|l|}{ Years from the birth } \\
\hline Pregnancy year & 8.106 & 8.284 \\
\hline 1 year after & 7.917 & 8.115 \\
\hline \multicolumn{3}{|l|}{ Decomposition } \\
\hline Difference & $0.189 * * *$ & $0.169^{* * *}$ \\
\hline Endowments & $0.236 * * *$ & $0.263 * * *$ \\
\hline Coefficients & -0.011 & $-0.154 * * *$ \\
\hline Interaction & -0.036 & 0.061 \\
\hline \multicolumn{3}{|l|}{ Endowments } \\
\hline \multicolumn{3}{|l|}{ Satisfaction with } \\
\hline Relationship with partner & $0.079^{* * * *}$ & $0.123 * * *$ \\
\hline Work & 0.000 & 0.001 \\
\hline Work-family balance & -0.001 & 0.006 \\
\hline Financial situation & 0.019 & 0.016 \\
\hline Employment prospects & 0.020 & 0.012 \\
\hline Job security & 0.001 & -0.001 \\
\hline Parents & 0.005 & -0.001 \\
\hline Leisure time & $0.034 * * *$ & $0.037 *$ \\
\hline Health & $0.038 * * *$ & $0.064 * * *$ \\
\hline Neighbourhood & 0.006 & 0.000 \\
\hline Job & 0.003 & -0.015 \\
\hline Pay & 0.001 & 0.000 \\
\hline Working hours & 0.000 & 0.000 \\
\hline Community & 0.000 & -0.015 \\
\hline Housing & 0.015 & $0.029 * *$ \\
\hline Safety & 0.016 & 0.007 \\
\hline
\end{tabular}

$* * *$ For $p=0.001 ; * *$ for $p=0.01 ; *$ for $p=0.05$ 
and is used to interpret differences of overall life satisfaction before and after the arrival of the first child. The mean level of life satisfaction is higher during the pregnancy year for both women and men, and the difference between the two time points is significant. The endowment coefficients are significant in both cases, meaning that differences in life satisfaction are significantly explained by differences in explanatory factors between the two groups. The results in the "Endowments" part support our previous graphical analysis in Sect. 4, where we plotted the predicted satisfaction levels for separate domains based on fixed effect regressions. For men, we see that satisfaction with the partner, leisure time, and health are the domains that matter for overall life satisfaction surrounding the childbearing event. For women, the same domains matter, though we also find that satisfaction with housing matters significantly. In terms of the magnitude, satisfaction with the partner is by far the most important one, followed by satisfaction with health. Satisfaction with leisure time and housing, though significant, matters less than the other two domains.

In Tables 2 and 3 we extend the analysis by considering the decomposition of overall life satisfaction by comparing the year of childbirth and subsequent years up to $t+4$, and again we do this separately for men and women. As one can see, for both men and women, overall life satisfaction declines over these time periods, and focusing on the reported differences, we see that the decline is more pronounced for women, though it stabilises after $t+3$. When looking to the domains, we find again that the same three stand out: Satisfaction with the partner, leisure time and healththough for women, satisfaction with leisure time does not contribute to explaining the difference between men and women for the first time period. In terms of relative importance (in explaining the change in overall life satisfaction), we see that over time, satisfaction with the partner exceeds that of health and leisure time.

For men (Table 3), we also see a sharp decline, but there is not much difference across the time periods following the time of childbirth. In other words, the difference between the time of childbirth and other time periods are similar. As for the domains, the most striking difference compared with women is that satisfaction with leisure time is not significant in explaining the decline in men's overall satisfaction. Satisfaction with the partner, in contrast, becomes stronger across the time period in explaining the decline in overall satisfaction. As for women, men's reported satisfaction with health is significant in explaining the decline in overall satisfaction.

\section{Discussion}

The vast majority of studies looking into the relationship between childbearing and SWB use overall measures where respondents either report their general level of happiness or their life satisfaction. This literature shows that SWB tends to increase before childbirth and to decrease in the short term after the event. While this literature has caused considerable interest among social scientists, there has been substantial doubt about the underlying mechanisms and the actual meaning once childbearing is reported as affecting individuals' overall well-being, and certainly, there is considerable disagreement about the extent to which children bring about greater happiness and life satisfaction, or not. However, life satisfaction—or happiness-are intuitively multidimensional concepts, simply because 


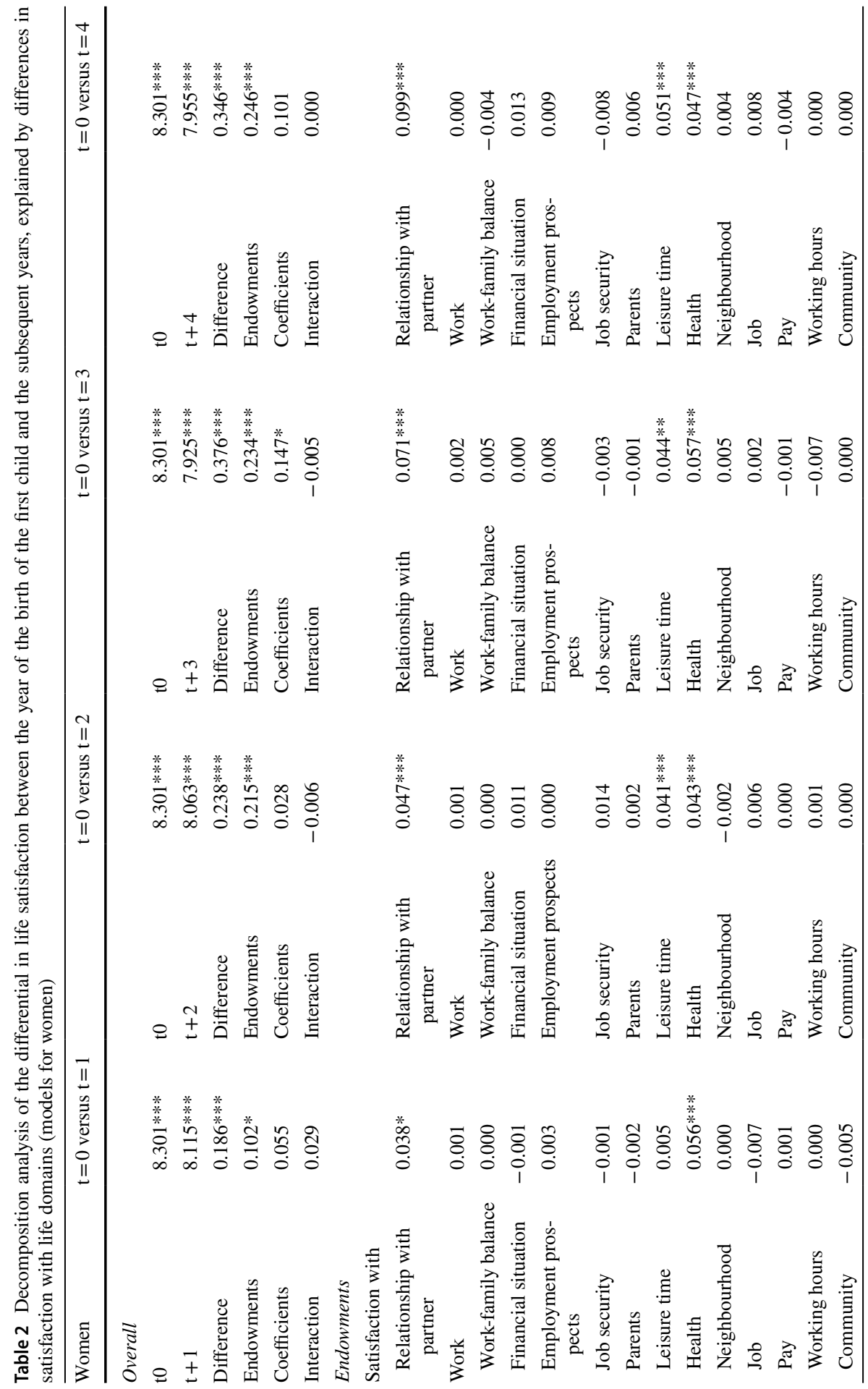




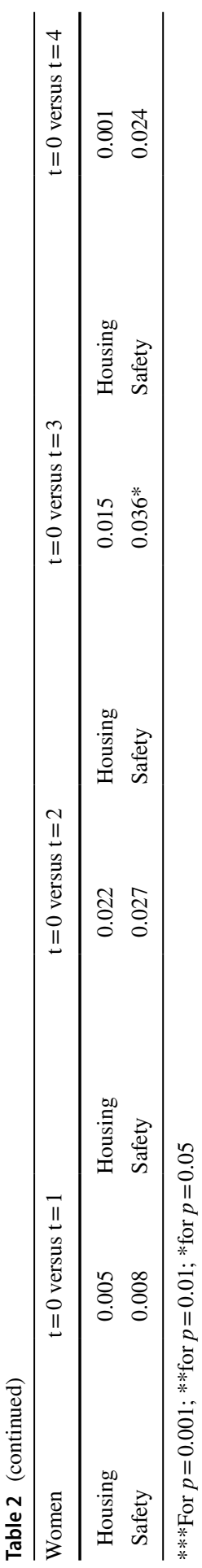




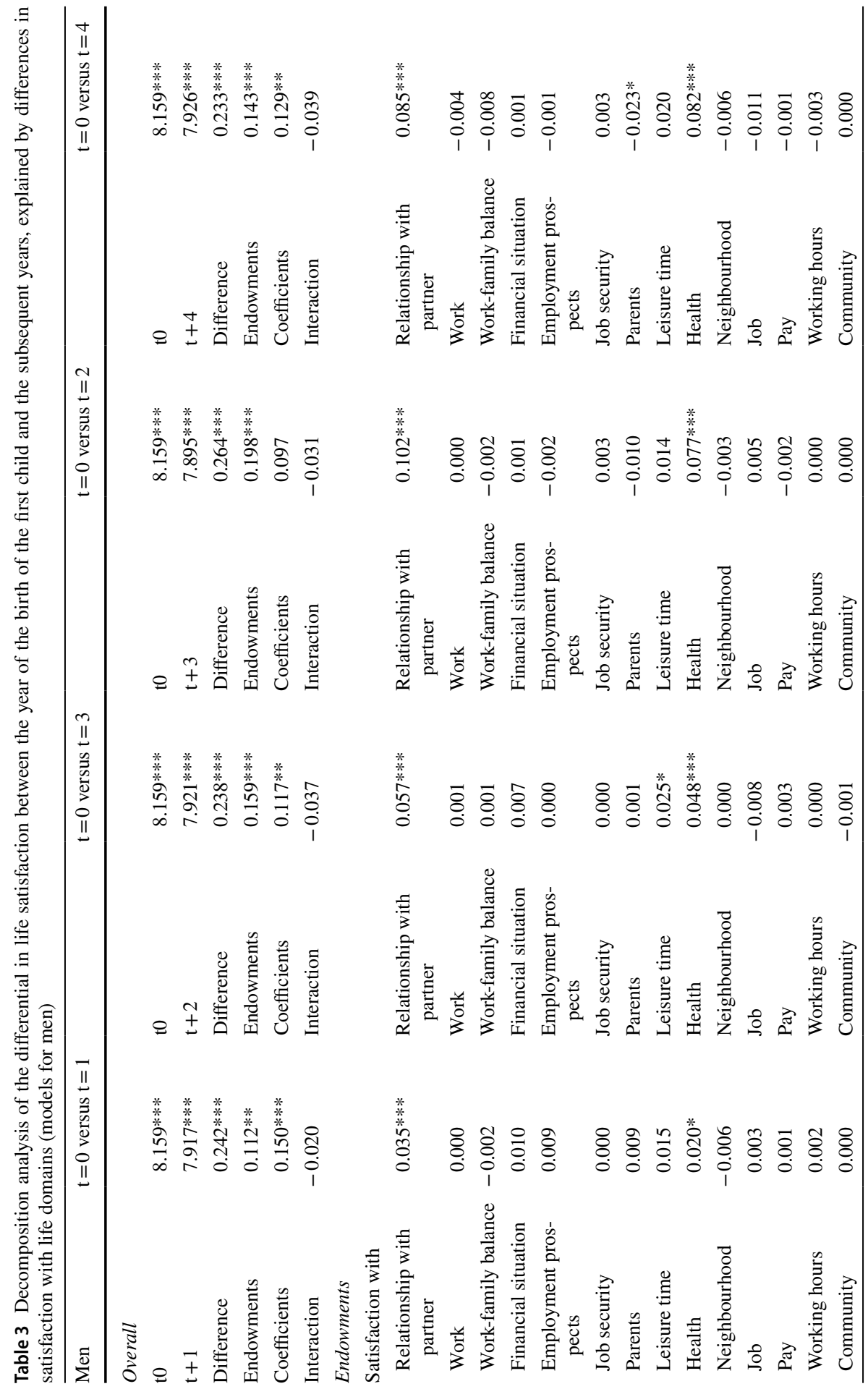




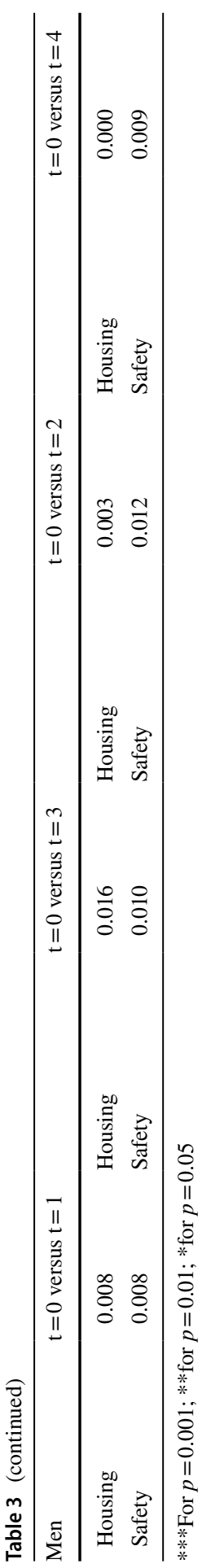


there cannot be only one aspect that affects individuals' well-being. In this analysis, by considering specific domains, these features come out very clearly. Whereas all the domains matter for the overall life satisfaction, only three of them, namely satisfaction with leisure, health, and satisfaction with the partnership, change significantly surrounding childbearing events. Even though we cannot generalise (since these results stem from one particular panel survey), it appears that the typical anticipation and decrease of overall satisfaction so often found in existing studies, stems from changes in these three domains. At the same time, all the other domains — and also the individual's values, aspirations and personality dispositions - are responsible for buffering and smoothing the ups and downs and make the trend of the overall satisfaction flatter.

Another important insight from this analysis is that for women the leisure and partnership relationship domains appear to suffer a relatively long-lasting decline in satisfaction after childbearing, ending lower than the original level observed four years prior to the childbearing event. With decomposition analysis, these conjectures are confirmed. Indeed, the three domains of leisure, health and satisfaction with the partner explain the change in overall life-satisfaction surrounding childbirth. This is an interesting finding, because satisfaction on these two domains does not show adaptation tendencies.

The fact that satisfaction with the partner and leisure are sensitive to childbearing events makes intuitive sense. Childbearing is a joint decision and is experienced by the two partners in the couple. As such, a childbearing event will necessarily involve the partner in important ways. The fact that this domain declines so strongly, suggests firstly, that the presence of children tends to compromise the harmony of the couple, potentially bringing about more conflict especially regarding the division of housework and childcare tasks (Doss et al., 2009; Gallie \& Russel, 2008; Keizer, 2013; LaRossa \& LaRossa, 1981). Secondly, children are time consuming and impose a tremendous change to the daily chores of the household, naturally reducing leisure time and time for a couple's intimacy (LaRossa \& LaRossa, 1981). The fact that women suffer much more than men in terms of their satisfaction with leisure time suggests that the burden tends to fall on women. However, this idea relates to well-known arguments. Mothers are more exposed to demands from parenting, because they are in charge of the primary childcare (Ross \& Van Willigen, 1996; Simon, 1992). Being the primary caregiver implies more challenges in reconciling family and work commitment and, as a consequence, higher indirect costs of childbearing for mothers doing the "second-shift" (Craig \& Siminski, 2010; Hochschild and Machung, 1989). Some authors have theorised and empirically tested that high indirect costs of childrearing for mothers might be a cause for lower fertility both at the macro (McDonald, 2001, 2013) and micro level (Campione, 2008; Kalmuss et al., 1992; Ruble et al., 1988). The finding that partner relationship and leisure domains stand out has useful theoretical implications. So far, existing studies based on overall life satisfaction or happiness are rather non-theoretical in the sense that it is difficult to infer the underlying mechanisms for exactly why childbearing events should bring about a change in a general subjective well-being measure.

\section{Appendix}

See Figs. 3, 4 and Tables 4, 5, 6, 7 and 8. 


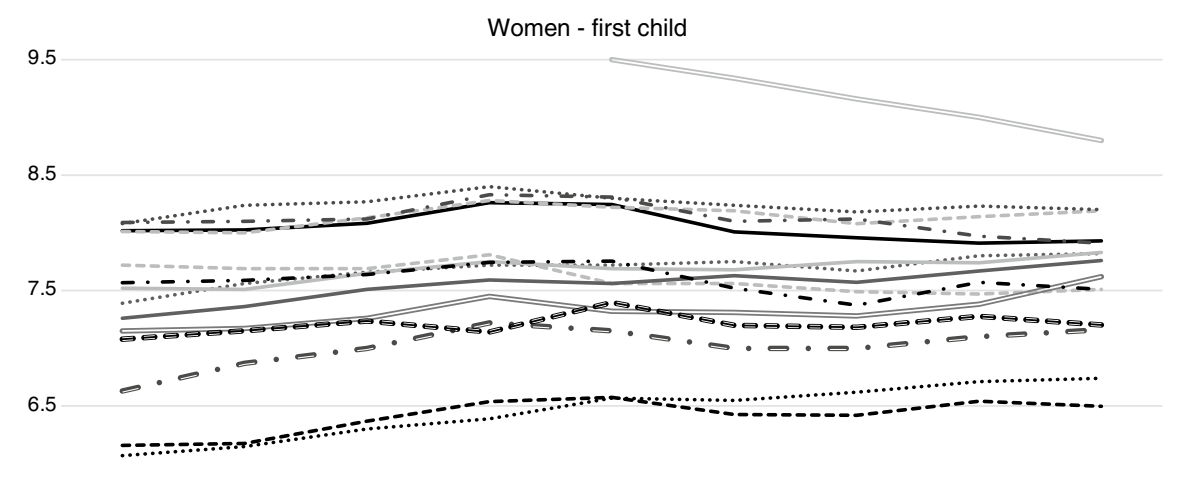

5.5

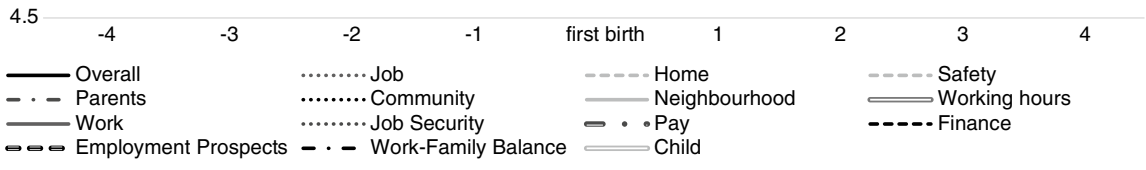

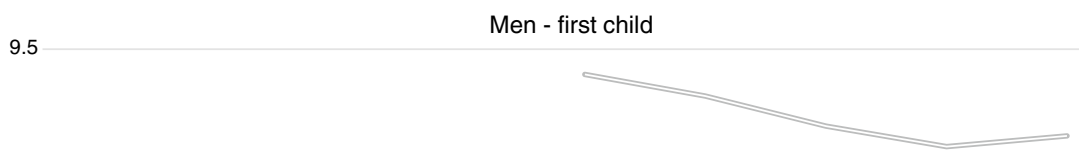

8.5

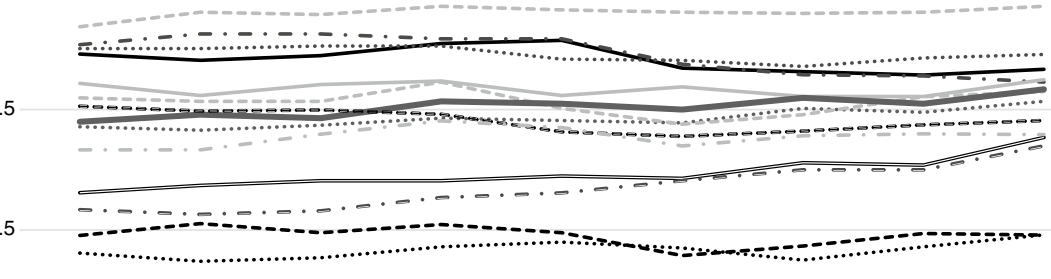

5.5

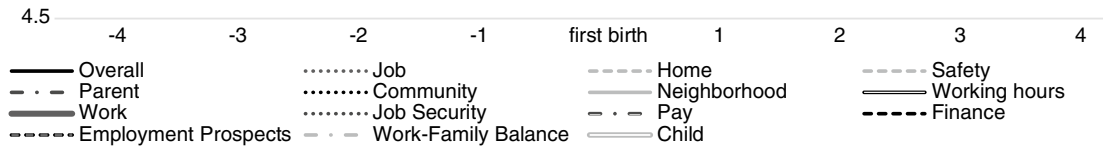

Fig. 3 Trajectories over time of other domains of satisfaction and of the overall life satisfaction, for women and men, across the transition to the first child (fixed effects, controlling for socio-demographic characteristics and other life events. Reference categories: 4 years before childbirth; $31-35$ years old; primary education; working full-time). Note 1: control variables are age classes, working conditions-i.e., inactive/unemployed; part-time less than $36 \mathrm{~h} /$ week; full-time 36- $40 \mathrm{~h} /$ week; full-time more than $40 \mathrm{~h} /$ week, equivalent household income, health conditions, experience of separation/divorce, experience of death of partner/close relative or friend, pregnancy of another child, birth of another child, age classes, level of education 


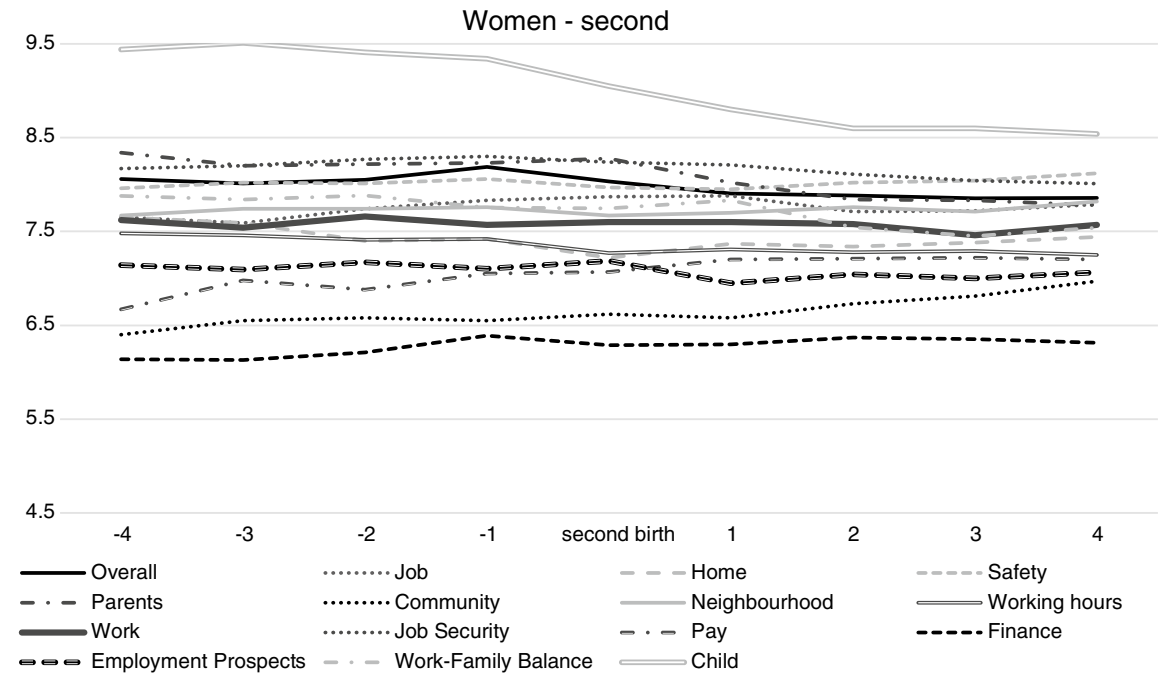

9.5

Men - second child

8.5

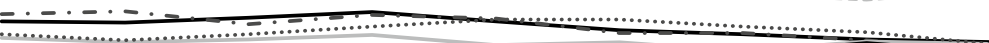

7.5

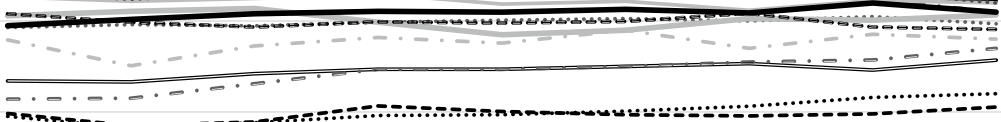

5.5

4.5

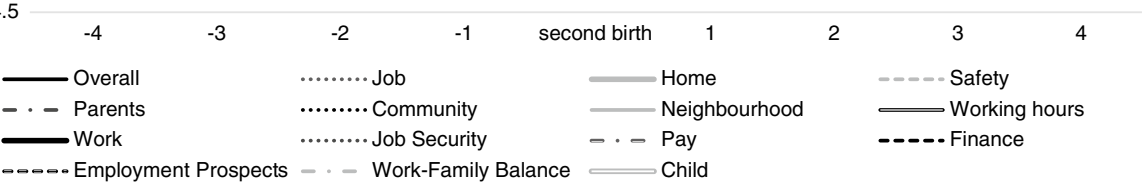

Fig. 4 Trajectories over time of other domains of satisfaction and of the overall life satisfaction, for women and men, across the transition to the second child (fixed effects, controlling for socio-demographic characteristics and other life events. (Reference categories: 4 years before childbirth; 31-35 years old; primary education; working full-time). Note 1: control variables are age classes, working conditions-i.e., inactive/unemployed; part-time less than $36 \mathrm{~h} /$ week; full-time 36-40 h/week; full-time more than $40 \mathrm{~h} /$ week, equivalent household income, health conditions, experience of separation/divorce, experience of death of partner/close relative or friend, pregnancy of another child, birth of another child, age classes, level of education. Note 2: dots indicate the coefficient is significant at least at $p=0.05$ 


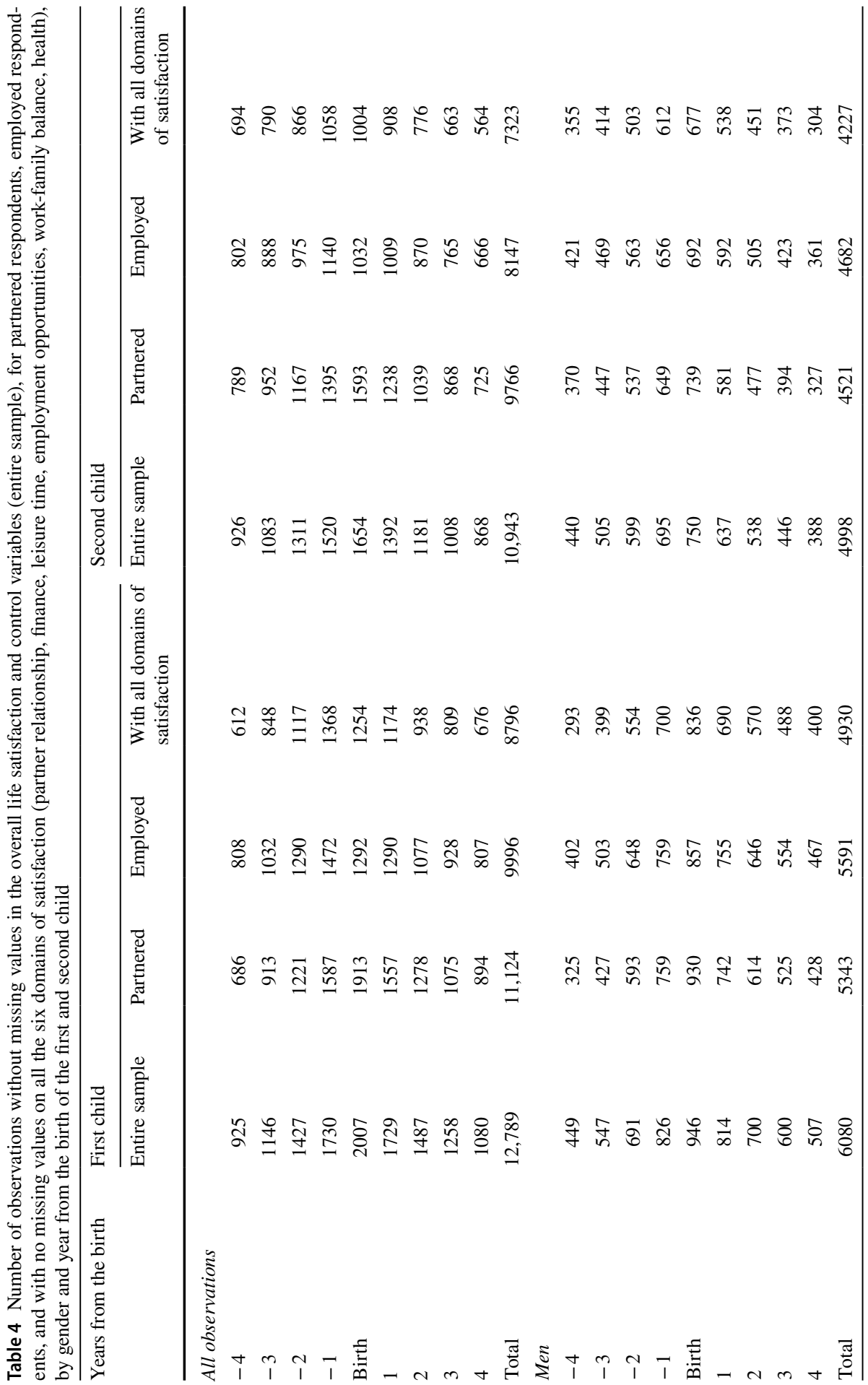




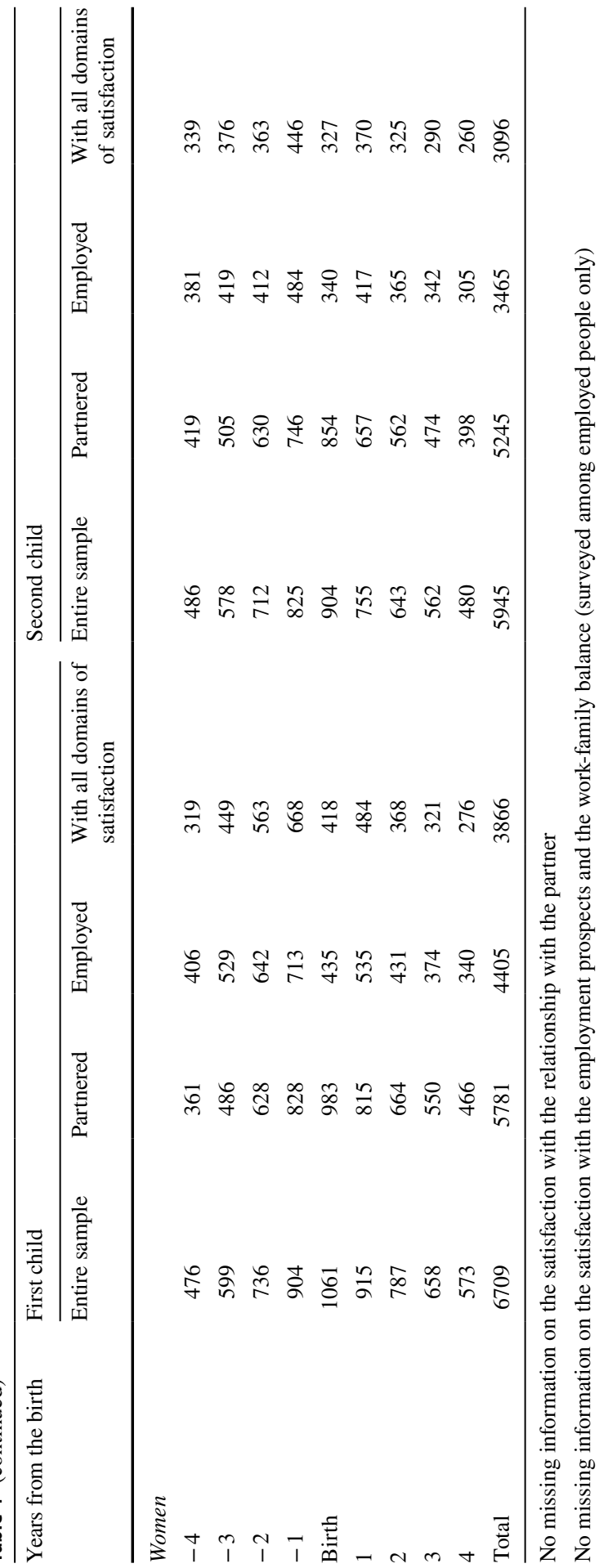


Table 5 Sample distribution around the main socio-demographic characteristics at the year of the birth of the first or second child, by gender

\begin{tabular}{|c|c|c|c|c|c|c|c|c|}
\hline & \multicolumn{4}{|c|}{ First child } & \multicolumn{4}{|c|}{ Second child } \\
\hline & \multicolumn{2}{|c|}{ All observations } & \multicolumn{2}{|c|}{$\begin{array}{l}\text { With no missing } \\
\text { domains satisfac- } \\
\text { tion }\end{array}$} & \multicolumn{2}{|c|}{ All observations } & \multicolumn{2}{|c|}{$\begin{array}{l}\text { With no missing } \\
\text { domains satisfac- } \\
\text { tion }\end{array}$} \\
\hline & Men & Women & Men & Women & Men & Women & Men & Women \\
\hline \multicolumn{9}{|l|}{ Age class } \\
\hline$\leq 20$ & 173 & 502 & 69 & 136 & 32 & 157 & 17 & 32 \\
\hline $21-25$ & 1107 & 1615 & 778 & 774 & 509 & 901 & 374 & 307 \\
\hline $26-30$ & 1719 & 1946 & 1435 & 1267 & 1085 & 1582 & 902 & 827 \\
\hline $31-35$ & 1676 & 1696 & 1466 & 1145 & 1578 & 1928 & 1400 & 1142 \\
\hline $36-40$ & 896 & 757 & 773 & 442 & 1137 & 1125 & 988 & 634 \\
\hline $41-45$ & 505 & 191 & 409 & 102 & 658 & 254 & 546 & 154 \\
\hline \multicolumn{9}{|l|}{ Employment status } \\
\hline Inactive/unemployed & 494 & 2315 & 0 & 0 & 323 & 2494 & 0 & 0 \\
\hline Part-time & 452 & 1957 & 366 & 1666 & 305 & 2101 & 275 & 1875 \\
\hline Full-time & 2135 & 1583 & 1874 & 1424 & 1727 & 884 & 1564 & 795 \\
\hline More than $40 \mathrm{~h} /$ week & 2999 & 854 & 2686 & 768 & 2644 & 468 & 2385 & 417 \\
\hline \multicolumn{9}{|l|}{ Level of education } \\
\hline Primary & 912 & 1146 & 533 & 370 & 669 & 983 & 464 & 265 \\
\hline Secondary & 3331 & 2945 & 2764 & 1646 & 2725 & 2670 & 2316 & 1336 \\
\hline Tertiary & 1838 & 2617 & 1633 & 1850 & 1605 & 2294 & 1447 & 1495 \\
\hline Total & 6081 & 6708 & 4930 & 3866 & 4999 & 5947 & 4227 & 3096 \\
\hline
\end{tabular}




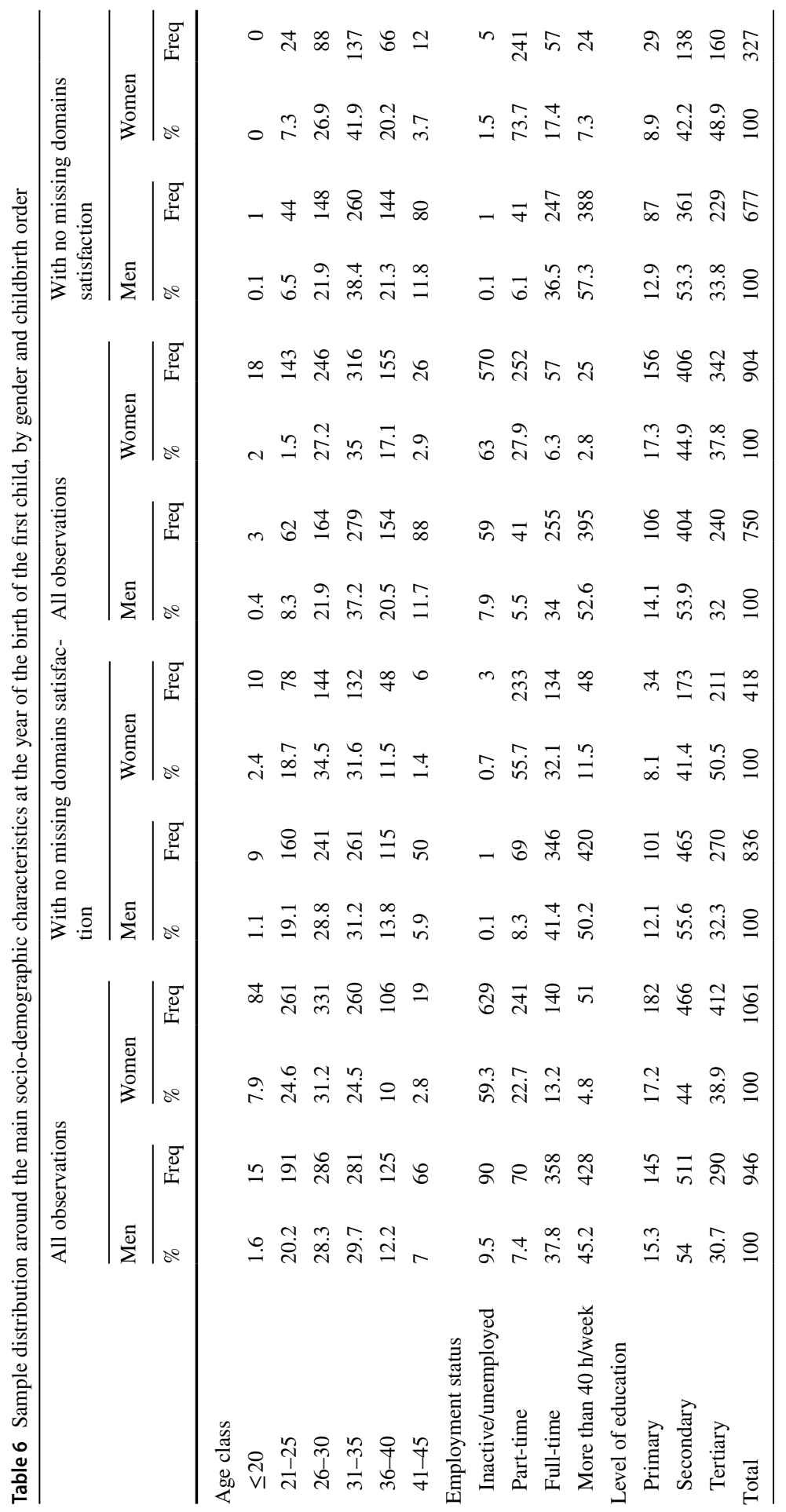




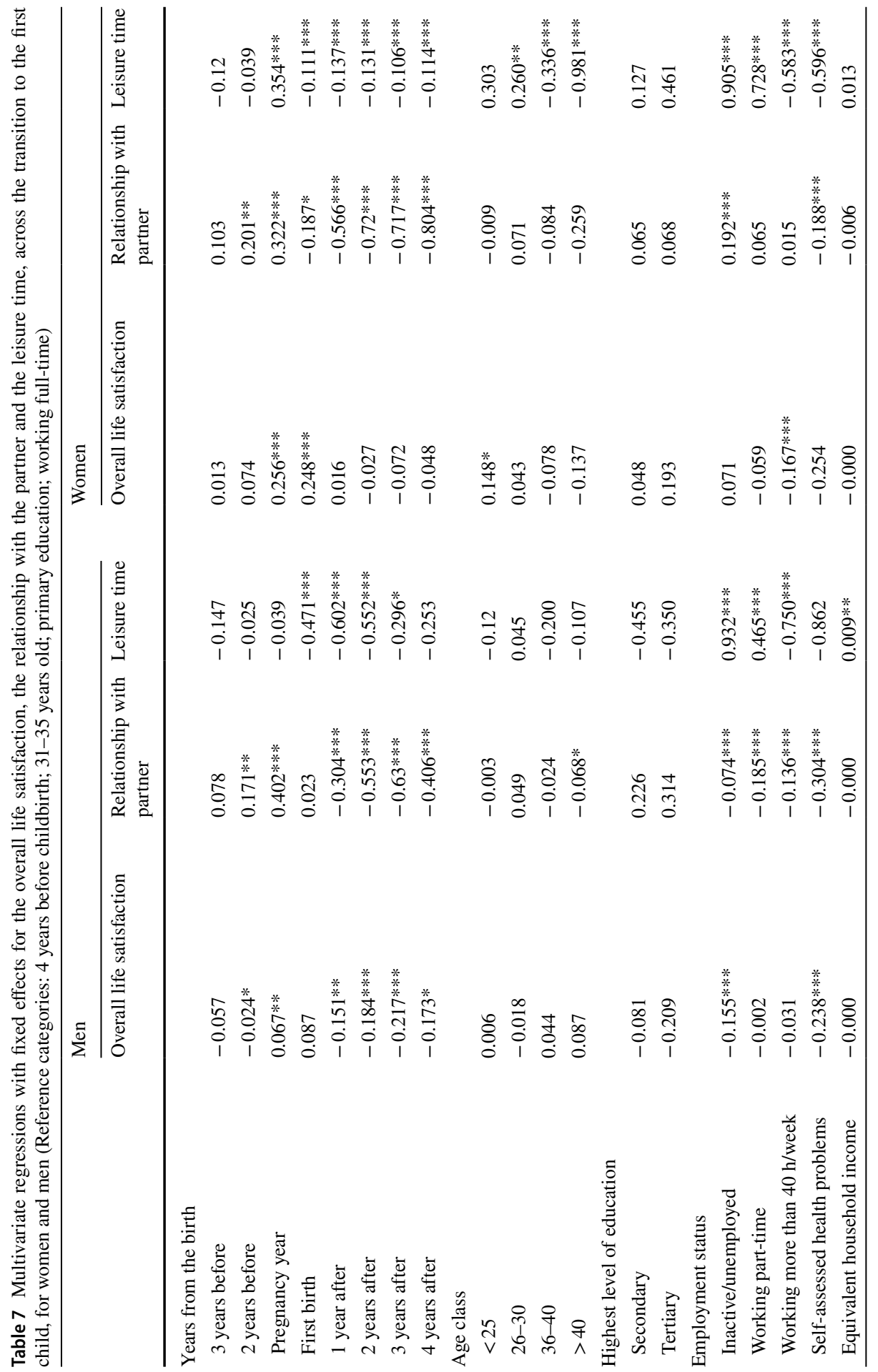




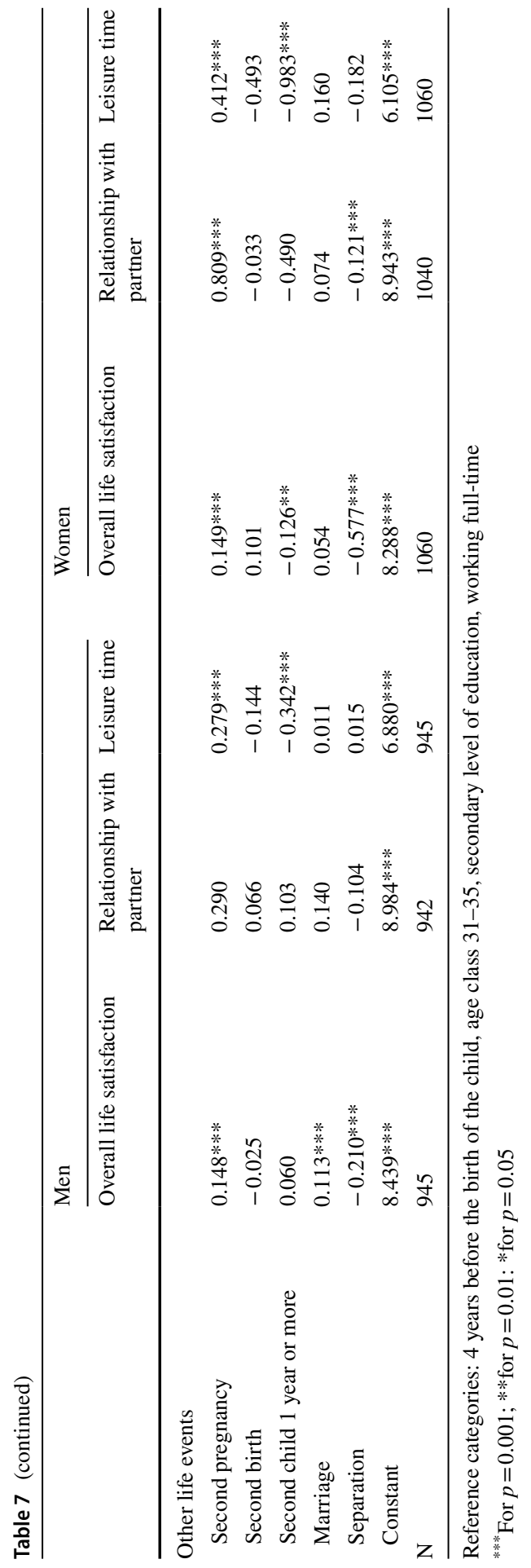




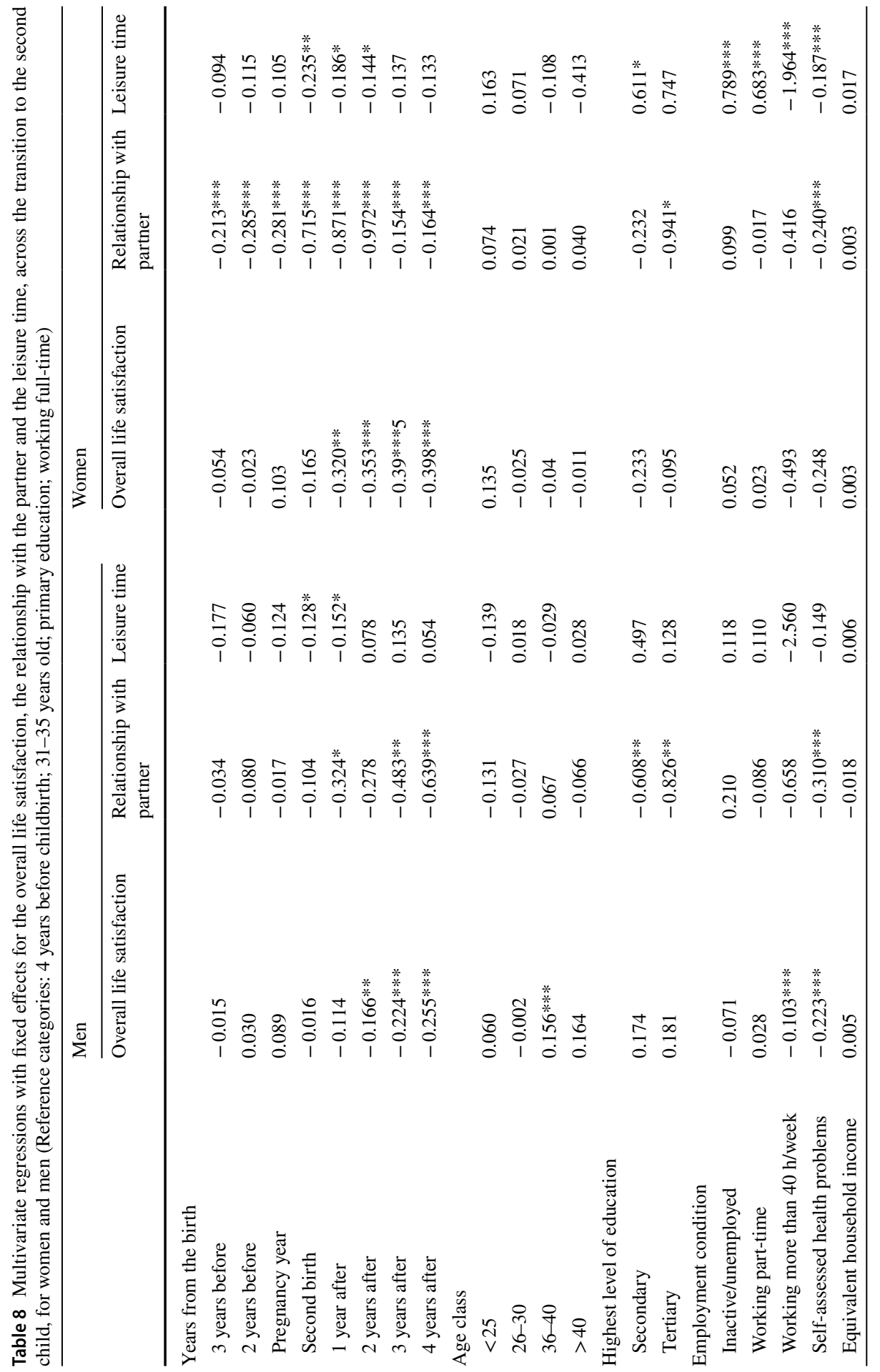




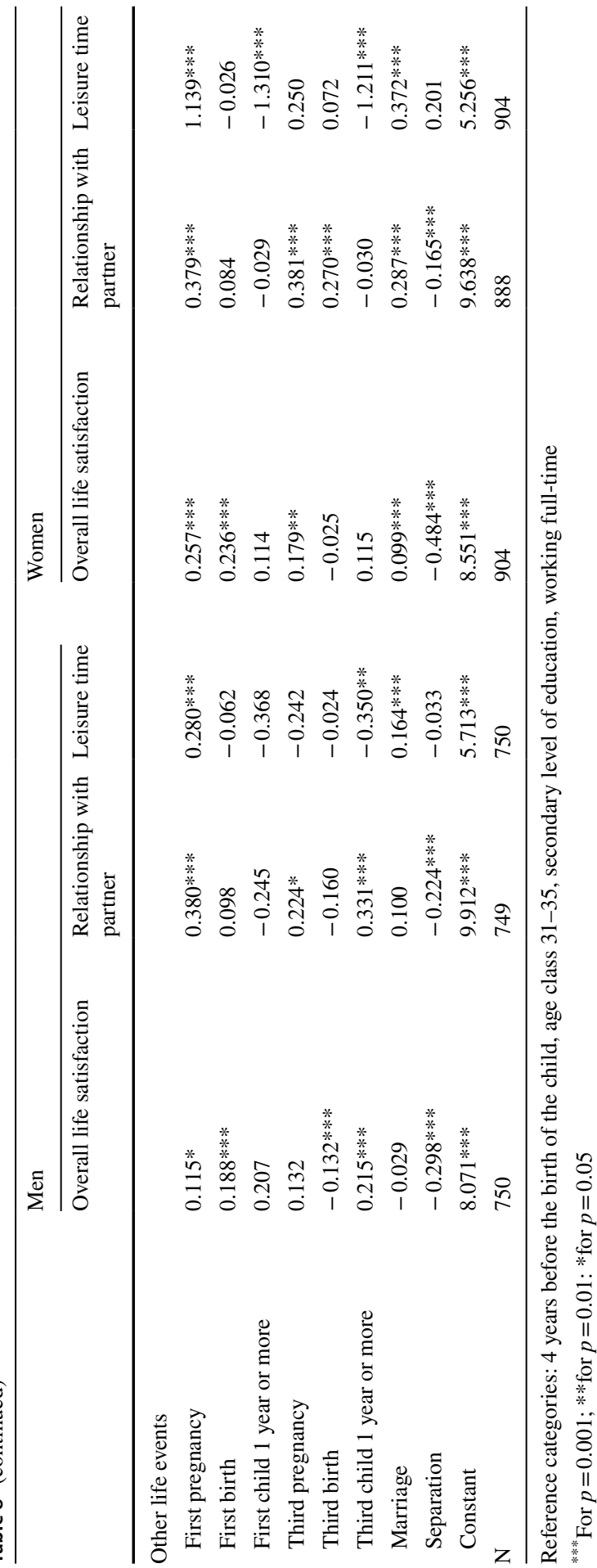


Acknowledgements The authors gratefully acknowledge financial support from the European Research Council under the European ERC Grant Agreement no StG-313617 (SWELL-FER: Subjective Wellbeing and Fertility, P.I. Letizia Mencarini).

Funding Open access funding provided by Università Commerciale Luigi Bocconi within the CRUICARE Agreement.

Open Access This article is licensed under a Creative Commons Attribution 4.0 International License, which permits use, sharing, adaptation, distribution and reproduction in any medium or format, as long as you give appropriate credit to the original author(s) and the source, provide a link to the Creative Commons licence, and indicate if changes were made. The images or other third party material in this article are included in the article's Creative Commons licence, unless indicated otherwise in a credit line to the material. If material is not included in the article's Creative Commons licence and your intended use is not permitted by statutory regulation or exceeds the permitted use, you will need to obtain permission directly from the copyright holder. To view a copy of this licence, visit http://creativecommons.org/licen ses/by/4.0/.

\section{References}

Aassve, A., Goisis, A., \& Sironi, M. (2012). Happiness and childbearing across Europe. Social Indicators Research, 108(1), 65-86.

Aassve, A., Mencarini, L., \& Sironi, M. (2015). Institutional change, happiness, and fertility. European Sociological Review, 31(6), 749-765.

Andrews, F. M., \& Withey, S. B. (1974). Developing measures of perceived life quality: Results from several national surveys. Social Indicators Research, 1(1), 1-26.

Argyle, M. (2001). The psychology of happiness. Routledge.

Argyle, M., \& Furnham, A. (1983). Sources of satisfaction and conflict in long-term relationships. Journal of Marriage and the Family, 45, 481-493.

Argyle, M., \& Martin, M. (1991). The psychological causes of happiness. In F. E. Strack, M. E. Argyle, \& N. E. Schwarz (Eds.), Subjective well-being: An interdisciplinary perspective (pp. 77-100). Pergamon Press.

Arpino, B., \& Luppi, F. (2020). Childcare arrangements and working mothers' satisfaction with workfamily balance. Demographic Research, 42(19), 549-588.

Bargh, J. A. (1989). Conditional automaticity: Varieties of automatic influence in social perception and cognition. Unintended Thought, 3, 51-69.

Bass, B. C. (2014). Preparing for parenthood? Gender, aspirations, and the reproduction of labor market inequality. Gender and Society, 29, 362-385.

Baxter, J., Buchler, S., Perales, F., \& Western, M. (2015). A life-changing event: First births and men's and women's attitudes to mothering and gender divisions of labour. Social Forces, 93(3), 989-1014.

Bernardi, L., Bollmann, G., Potarca, G., \& Rossier, J. (2017). Multidimensionality of well-being and spillover effects across life domains: How do parenthood and personality affect changes in domainspecific satisfaction? Research in Human Development, 14(1), 26-51.

Billari, F., \& Kohler, H. P. (2004). Patterns of low and lowest-low fertility in Europe. Population Studies, 58(2), 161-176.

Blinder, A. S. (1973). Wage discrimination: Reduced form and structural estimates. Journal of Human Resources, 8, 436-455.

Brehaut, J. C., Garner, R. E., Miller, A. R., Lach, L. M., Klassen, A. F., Rosenbaum, P. L., \& Kohen, D. E. (2011). Changes over time in the health of caregivers of children with health problems: Growthcurve findings from a 10-year Canadian population-based study. American Journal of Public Health, 101(12), 2308-2316.

Campbell, A., Converse, P. E., \& Rodgers, W. L. (1976). The quality of American life: Perceptions, evaluations, and satisfactions. Russell Sage Foundation.

Campione, W. (2008). Employed women's well-being: The global and daily impact of work. Journal of Family and Economic Issues, 29(3), 346-361. 
Cantor, N., \& Blanton, H. (1996). Effortful pursuit of personal goals in daily life. In P. M. Gollwitzer \& J. A. Bargh (Eds.), The psychology of action: Linking cognition and motivation to behaviour (pp. 338-359). Guilford Press.

Cantor, N., \& Sanderson, C. A. (1999). Life task participation and well-being: The importance of taking part in daily life. In D. Kahneman, E. Diener, \& N. Schwarz (Eds.), Well-being: The foundations of hedonic psychology. Russell Sage Foundation.

Clark, A. E., Diener, E., Georgellis, Y., \& Lucas, R. E. (2008). Lags and leads in life satisfaction: A test of the baseline hypothesis. The Economic Journal, 118(529), 222-243.

Condon, J. T., Boyce, P., \& Corkindale, C. J. (2004). The first-time fathers study: A prospective study of the mental health and well-being of men during the transition to parenthood. Australian and New Zealand Journal of Psychiatry, 38(1-2), 56-64.

Costa, S. (2008). Quality of life in remote mining communities: A multiple case study in the Brazilian Amazon. Dissertation, The University of British Columbia (Vancouver).

Cowan, C. P., \& Cowan, P. A. (1992). When partners become parents: The big life change for couples. Basic Books.

Craig, L., Mullan, K., \& Blaxland, M. (2010). Parenthood, policy and work-family time in Australia 1992-2006. Work, Employment and Society, 24(1), 27-45.

Craig, L., \& Siminski, P. (2010). Men's housework, women's housework, and second births in Australia. Social Politics, 17(2), 235-266.

Cummins, R. A. (1996). The domains of life satisfaction: An attempt to order chaos. Social Indicators Research, 38(3), 303-328.

Davis, E., Shelly, A., Waters, E., Boyd, R., Cook, K., \& Davern, M. (2009). The impact of caring for a child with cerebral palsy: Quality of life for mothers and father. Childcare, Heal Development, 36, 63-73.

Diener, E., Suh, E. M., Lucas, R. E., \& Smith, H. L. (1999). Subjective well-being: Three decades of progress. Psychological Bulletin, 125(2), 276-302.

Doss, B. D., Rhoades, G. K., Stanley, S. M., \& Markman, H. J. (2009). The effect of the transition to parenthood on relationship quality: An eight-year prospective study. Journal of Personality and Social Psychology, 96(3), 601-619.

Frijters, P., Johnston, D. V., \& Shields, M. A. (2011). Life satisfaction dynamics with quarterly life event data. Scandinavian Journal of Economics, 113(1), 190-211.

Furnham, A. (1991). Work and leisure satisfaction. In F. E. Strack, M. E. Argyle, \& N. E. Schwarz (Eds.), Subjective well-being: An interdisciplinary perspective (pp. 235-260). Pergamon Press.

Gallie, D., \& Russel, H. (2008). Work family conflict and working conditions in western Europe. Social Indicators Research, 93, 445-467.

Georgellis, Y., Lange, T., \& Tabvuma, V. (2012). The impact of life events on job satisfaction. Journal of Vocational Behavior, 80(2), 464-473.

Goldberg, A. E., \& Perry-Jenkins, M. (2004). Division of labor and working-class women's well-being across the transition to parenthood. Journal of Family Psychology, 18, 225-236.

Greenley, J. R., Greenberg, J. S., \& Brown, R. (1997). Measuring quality of life: A new and practical survey instrument. Social Work, 42(3), 244-254.

Grunow, D., Schulz, F., \& Blossfeld, H. P. (2012). What determines change in the division of housework over the course of marriage? International Sociology, 27(3), 289-307.

Headey, B., \& Wearing, A. (1992). Understanding happiness: A theory of subjective well-being. Longman Cheshire.

Hochschild, A., \& Machung, A. (1989). The second shift: Working parents and the revolution at home. New York, NY: Viking.

Inglehart, R. (1977). The silent revolution. Princeton University Press.

Inglehart, R. (1989). Observations on cultural change and postmodernism. Contemporary political culture. Sage.

Jann, B. (2008). The Blinder-Oaxaca decomposition for linear regression models. The Stata Journal, $8(4), 453-479$.

Kabanoff, B. (1982). Occupational and sex differences in leisure needs and leisure satisfaction. Journal of Organizational Behavior, 3(3), 233-245.

Kalmuss, D., Davidson, A., \& Cushman, L. (1992). Parenting expectations, experiences, and adjustment to parenthood: A test of the violated expectations framework. Journal of Marriage and Family, 54(3), 516-526. 
Kasser, T., \& Ryan, R. M. (1996). Further examining the American dream: Differential correlates of intrinsic and extrinsic goals. Personality and Social Psychology Bulletin, 22, 280-287.

Keizer, R. (2013). Relationship satisfaction. In A. C. Michalos (Ed.), Encyclopedia of quality of life research. Springer.

Kline, C. R., Martin, D. P., \& Deyo, R. A. (1998). Health consequences of pregnancy and childbirth as perceived by women and clinicians. Obstetrics and Gynaecology, 92(5), 842-848.

Kohler, H. P., \& Mencarini, L. (2016). The parenthood happiness puzzle: An introduction to the special issue. European Journal of Population, 32, 327-338.

Krämer, M. D., \& Rodgers, J. L. (2019). The impact of having children on domain-specific life satisfaction: A quasi-experimental longitudinal investigation using the socio-economic panel (SOEP) data. Journal of Personality and Social Psychology., 119, 1497-1514.

Lance, C. E., Lautenschlager, G. J., Sloan, C. E., \& Varca, P. E. (1989). A comparison between bottomup, top-down, and bidirectional models of relationships between global and life facet satisfaction. Journal of Personality, 57(3), 601-624.

LaRossa, R., \& LaRossa, M. M. (1981). Transition to parenthood. Sage Publications.

Le Moglie, M., Mencarini, L., \& Rapallini, C. (2015). Is it just a matter of personality? On the role of subjective well-being in childbearing behavior. Journal of Economic Behavior and Organization, $117,453-475$.

Le Moglie, M., Mencarini, L., \& Rapallini, C. (2018). Does income moderate the parental satisfaction after the birth of the first child: In Germany it does and depends on education. Journal of Population Economics, 32, 915-952.

Lesthaeghe, R., \& van de Kaa, D. (1986). Twee demografische transities? [Two demographic transitions?]. In R. Lesthaeghe \& D. van de Kaa (Eds.), Bevolking-Groei en Krimp, Mens en Maatschappij (pp. 9-24). Van Loghum Slaterus.

Liefbroer, A. C. (2005). The impact of perceived costs and rewards of childbearing on entry into parenthood: Evidence from a panel study. European Journal of Population/revue Européenne De Démographie, 21(4), 367-391.

Margolis, R., \& Myrskylä, M. (2011). A global perspective on happiness and fertility. Population and Development Review, 37(1), 29-56.

Matysiak, A., Mencarini, L., \& Vignoli, D. (2016). Work-family conflict moderates the relationship between childbearing and subjective well-being. European Journal of Population, 32(3), 355-379.

McDonald, P. (2000). Gender equity in theories of fertility transition. Population and Development Review, 26(3), 427-439.

McDonald, P. (2001). Theory pertaining to low fertility. ANU Research Publications.

McDonald, P. (2013). Societal foundations for explaining low fertility: Gender equity. Demographic Research, 28, 981-994.

Melender, H. L., \& Lauri, S. (2002). Experiences of security associated with pregnancy and childbirth: A study of pregnant women. International Journal of Nursing Practice, 8(6), 289-296.

Mikula, G., Riederer, B., \& Bodi, O. (2012). Perceived justice in the division of domestic labor: Actor and partner effects. Personal Relationships, 19(4), 680-695.

Morgan, S. P. (2003). Is low fertility a twenty-first-century demographic crisis? Demography, 40(4), 589-603.

Myrskylä, M., \& Margolis, R. (2014). Happiness: Before and after the kids. Demography, 51, 1843-1866.

Oaxaca, R. (1973). Male-female wage differentials in urban labor markets. International Economic Review, 14, 693-709.

OECD. (2012). Family database. https://www.oecd.org/els/family/database.htm.

Oishi, S., Diener, E., Suh, E., \& Lucas, R. E. (1999). Value as a moderator in subjective well-being. Journal of Personality, 67, 157-184.

Pavot, W., \& Diener, E. (2008). The satisfaction with life scale and the emerging construct of life satisfaction. Journal of Positive Psychology, 3, 137-152.

Pollmann-Schult, M. (2014). Parenthood and life satisfaction: Why don't children make people happy? Journal of Marriage and the Family, 76, 319-336.

Praag, B., Frijtersvan, P., \& Ferrer-i-Carbonell, A. (2003). The anatomy of subjective well-being. Journal of Economic Behavior and Organization, 51, 29-49.

Ross, C. E., \& Van Willigen, M. (1996). Gender, parenthood, and anger. Journal of Marriage and the Family, 58, 572-584. 
Ruble, D. N., Fleming, A. S., Hackel, L. S., \& Stangor, C. (1988). Changes in the marital relationship during the transition to first time motherhood: Effects of violated expectations concerning division of household labor. Journal of Personality and Social Psychology, 55, 78-87.

Ruppanner, L., Brandén, M., \& Turunen, J. (2018). Does unequal housework lead to divorce? Evidence from Sweden. Sociology, 52(1), 75-94.

Saris, W. E., \& Ferligoj, A. (1995). Life-satisfaction and domain-satisfaction in 10 European countries: Correlation at the individual level. In W. E. Saris (Ed.), A comparative study of satisfaction with life in Europe (pp. 275-279). Eötvös University Press.

Schwarz, N., \& Strack, F. (1991). Evaluating one's life: A judgment model of subjective well-being. In F. E. Strack, M. E. Argyle, \& N. E. Schwarz (Eds.), Subjective well-being: An interdisciplinary perspective (pp. 27-48). Pergamon Press.

Schwarz, N., Strack, F., Kommer, D., \& Wagner, D. (1987). Soccer, rooms, and the quality of your life: Mood effects on judgments of satisfaction with life in general and with specific domains. European Journal of Social Psychology, 17(1), 69-79.

Simon, R. W. (1992). Parental role strains, salience of parental identity and gender differences in psychological distress. Journal of Health and Social Behavior, 33, 25-35.

Steptoe, A., Deaton, A., \& Stone, A. A. (2015). Subjective well-being, health, and ageing. The Lancet, 385(9968), 640-648.

Trauer, T., \& Mackinnon, A. (2001). Why are we weighting? The role of importance ratings in quality of life measurement. Quality of Life Research, 10(7), 579-585.

Twenge, J. M., Campbell, W. K., \& Craig, A. (2003). Parenthood and marital satisfaction: A meta-analytic review. Journal of Marriage and Family, 65(3), 574-583.

Veenhoven, R. (1996). Developments in satisfaction-research. Social Indicators Research, 37(1), 1-46.

Veroff, J., Douvan, E. A. M., \& Kulka, R. A. (1981). The inner American: A self-portrait from 1957 to 1976. Basic Books.

Webb, D. A., Bloch, J. R., Coyne, J. C., Chung, E. K., Bennett, I. M., \& Culhane, J. F. (2008). Postpartum physical symptoms in new mothers: Their relationship to functional limitations and emotional wellbeing. Birth, 35(3), 179-187.

Wu, C. H. (2009). Enhancing quality of life by shifting importance perception among life domains. Journal of Happiness Studies, 10(1), 37-47.

Yavorsky, J. E., Kamp Dush, C. M., \& Schoppe-Sullivan, S. J. (2015). The production of inequality: The gender division of labor across the transition to parenthood. Journal of Marriage and Family, 77(3), $662-679$.

Publisher's Note Springer Nature remains neutral with regard to jurisdictional claims in published maps and institutional affiliations. 